\title{
Pendekatan Pengembangan Metaheuristik dalam optimisasi kombinatorial
}

\author{
Muhammad Iqbal 1, Muhammad Zarlis ${ }^{2}$, Tulus ${ }^{3}$, Herman Mawengkang4 \\ ${ }^{1}$ Fakultas Ilmu Komputer dan Teknologi Informasi, Program Studi Doktor Ilmu Komputer, \\ Universitas Sumatera Utara, Medan, Indonesia \\ ${ }^{2}$ Fakultas Ilmu Komputer dan Teknologi Informasi, Program Studi Ilmu Komputer, Universitas \\ Sumatera Utara, Medan, Indonesia \\ 3,4 Fakultas Matematika dan Ilmu Pengetahuan Alam, Program Studi Matematika, Universitas \\ Sumatera Utara, Medan, Indonesia \\ ${ }^{1}$ muhammadiqbal@dosen.pancabudi.ac.id
}

\begin{abstract}
Abstrak- Masalah kombinatorial adalah masalah yang mempunyai himpunan solusi layak (feasible) yang terhingga. Meskipun secara prinsip solusi dari masalah ini bisa didapatkan dengan enumerasilengkap, pada masalah kompleks dibutuhkan waktuyang tidakbisa diterima secara praktis, analisis kombinatorial adalah studi matematika tentang pengaturan, pengelompokan, pemesanan, atau pemilihan objek diskrit, biasanya terbatas jumlahnya (finite in number), banyak masalah optimasi kombinatorial telah dihasilkan oleh penelitian dalam desain komputer, teori komputasi, dan oleh aplikasi komputer pada masalah numerik yang membutuhkan metode baru, pendekatan baru, dan wawasan matematika baru, pada optimisasi kombinatorial, fungsi $g(x)$ di defenisikan sebagai pemetaan $g:\{0,1\}^{n} \rightarrow\{0,1\}$, memperoleh daerah layak kebanyakan metode untuk menyelesaikan persoalan optimisasi kombinatorial mengajukan daerah layak, yaitu daerah yang di batasi kendala persoalan setelah dilakukan relaksasi seperti cacah atau biner terhadap variabel, Irisan bidang pada umumnya menggunakan metode metaheuristik yang telah diajukan para peneliti lain, misalnya Genetika algoritma, simulated annealing, tabu search, plant propagation, metode metode ini tidak mempergunakan konsep daerah layak, tapi mengajukan titik awal.
\end{abstract}

Kata Kunci: Model, Metaheuristik, Optimisasi

Abstract- Combinatorial problems are problems that have a finite set of feasible solutions. Although in principle the solution to this problem can be obtained with complete enumeration, in complex problems it takes time that cannot be practically accepted, combinatorial analysis is a mathematical study of the arrangement, grouping, ordering, or selection of discrete objects, usually limited in number (finite in number), many combinatorial optimization problems have been generated by research in computer design, computational theory, and by computer applications on numerical problems that require new methods, new approaches, and new mathematical insights, on combinatorial optimization, the function $g(x)$ is defined as mapping $g:\{0,1\} n \rightarrow\{0,1\}$, obtaining feasible regions Most methods for solving combinatorial optimization problems propose feasible regions, namely areas that are constrained by problem constraints after relaxation such as counts or binary variables, Field slices generally use the metaheuristic method proposed by para Other researchers, for example Genetic algorithms, simulated annealing, taboo search, plant propagation, methods do not use feasible regional concepts, but proposing the starting point for abstract completion is a brief summary of the paper to help readers quickly ascertain the research objectives and match the research needs.

Keywords: Model, Metaheuristic, Optimization 


\section{PENDAHULUAN}

Kebanyakan persoalan optimisasi baik yang ditinjau dari segi praktis maupun teoritis terdiri dari pencarian konfigurasi "terbaik" himpunan variable sedemikian hingga tercapainya tujuan (objektif). Peroalan demikian ini terbagi dalam dua kategori, yaitu, persoalan yang penyelesaiannya adalah variable berharga riel, dan persoalan yang variabelnya bernilai diskrit. Persoalan optimisasi dengan kategori kedua dikenal sebagai persoalan optimisasi kombinatorial. Yang selanjutnya dalam desertasi ini disingkat dengan CO. Menurut Papadimitriou dan Steiglitz (1982), dalam persoalan CO, perlu dicari suatu objek dari himpunan berhingga (atau mungkin infinit terhitung). Objek ini dapat berupa bilangan bulat, suatu himpunan bagian, suatu permutasi, atau suatu struktur graph. Jadi persoalan CO $\mathrm{P}=(\mathrm{S}, \mathrm{f})$ dapat didefinisikan sebagai persoalan yang mengandung

a) himpunan variabel $\mathrm{X}=\{\mathrm{x} 1, \ldots, \mathrm{xn}\}$;

b) domain variabel $\mathrm{D} 1, \ldots, \mathrm{Dn}$;

c) kendala terhadap variabel; dan

d) suatu fungsi objektif untuk diminimumkan $\mathrm{f}$.

Himpunan dari semua penugasan yang mungkin adalah

$\mathrm{S}=\left\{\mathrm{s}=\left\{\left(\mathrm{x}_{1}, \mathrm{v}_{1}\right), \ldots,\left(\mathrm{x}_{\mathrm{n}}, \mathrm{V}_{\mathrm{n}}\right)\right\} \mid \mathrm{v}_{\mathrm{i}} \in \mathrm{D}_{\mathrm{i}}, \mathrm{s}\right.$ memenuhi semua kendala $\}$.

$S$ biasanya disebut ruang pencarian (atau penyelesaian) karena setiap elemen dapat menjadi calon penyelesaian. Untuk menyelesaikan persoalan CO perlu ditentukan $\mathrm{s} * \in \mathrm{S}$ dengan nilai fungsi objektif minimum, yaitu, $\mathrm{f}(\mathrm{s} *) \leq \mathrm{f}(\mathrm{s}) \forall \mathrm{s} \in \mathrm{S}$. $\mathrm{s} *$ disebut penyelesaian optimal global dari $(\mathrm{S}, \mathrm{f})$ dan himpunan $\mathrm{S} * \subseteq \mathrm{S}$ disebut himpunan penyelesaian global.

Persoalan kombinatorial banyak muncul dalam aplikasi praktis. Beberapa pemakaian mencakup sektor-sektor, seperti, optimisasi portofolio investasi [1-2], rancangan layout dalam sektor servis dan manufaktur [3], rancangan terintegrasi dan terkendali proses kimia [4], system distribusi air minum [5], rantai suplai multiperiode [6], perancangan system energy [6], Perencanaan layout lokasi konstruksi [7].

Oleh karena itu perlu adanya algorithma yang mampu menyelesaikan persoalan CO secara efisien. Pendekatan algoritmik terhadap persoalan ini dapat dikelasifikasikan sebagai penyelesaian eksak atau pendekatan (approximate). Algoritma eksak dijamin untuk memperoleh suautu penyelesaian optimal dalam waktu berhingga dengan secara sistematis menjelajahi ruang penyelesaian. Metode eksak untuk menyelesaikan CO mencakup pendekatan inovatif dan teknik terkait yang diambil dan diperluas dari penyelesaian persoalan mixed integer programming (MIP), seperti metode Outer Approximation (OA) [8-10], Branchand-Bound (B \& B) [11-13], Extended Cutting Plane methods [Tamara G. Kolda, Robert M. Lewis.,2003], dan Generalized Bender's Decomposition (GBD) [14], yang untuk menyelesaikan CO telah dibahas dalam literatur sejak awal tahun 1980an. Metode-metode ini umumnya bergantung pada solusi berurutan dari persoalan nonlinear programming (NLP) berkaitan. Sebagai contoh, B \& B memulai dengan membentuk persoalan NLP kontinu murni dengan mengendorkan persyaratan integralitas dari variabel diskrit (sering disebut Relaksasi). Selain itu, setiap simpul dari pohon B \& B yang muncul merupakan solusi dari relaksasi dengan batas yang 
disesuaikan pada variabel diskrit. Baru-baru ini [7] mengembangkan pencarian Hooke-and-Jeeves terfilter untuk menyelesaikan CO. Vigerske dan Gleixner (2017) menyelesaikan CO dalam kerangka dasar metode Branch and Cut.

Namun, karena sifat NP-lengkap dari persoalan CO, waktu yang dibutuhkan tumbuh secara eksponensial untuk kasus terburuk. Untuk mengatasi persoalan ini secara praktis, penyelesaian terhadap CO dianggap telah memenuhi mendekati penyelesaian optimal dalam waktu polynomial. Inilah yang menjadi gol dari algoritma pendekatan seperti penjelajahan local. Algoritma pendekatan tidak dapat menjamin optimalitas penyelesaian, tapi secara empiris algoritma ini acapkali memperlihatkan hasil yang "baik" dalam waktu komputasi singkat.

Algoritma pendekatan yang paling banyak terpakai dan sukses adalah algoritma penjelajahan local. Algoritma ini mulai dari penyelesaian diberikan dan mencoba untuk menentukan penyelesaian lebih baik dalam daerah sekitar yang sesuai (melalui definisi) dari penyelesaian yang telah diperoleh. Jika suatu titik penyelesaian lebih baik ditemukan, maka titik ini menggantikan titik penyeleasian sebelumnya dan penjelajahan local berlanjut

\section{METODOLOGI PENELITIAN}

Bidang metaheuristik untuk aplikasi terhadap masalah optimasi kombinatorial adalah bidang penelitian yang berkembang pesat saat ini. Hal ini disebabkan pentingnya masalah optimasi kombinatorial untuk dunia ilmiah maupun industri. Peneliti dalam hal ini menguraikan berbagai komponen dan konsep yang digunakan dalam metaheuristik yang berbeda untuk menganalisis kesamaan dan perbedaannya. Dua konsep penting dalam metaheuristik adalah intensifikasi dan diversifikasi. Inilah dua kekuatan yang sangat menentukan dalam metaheuristik. Peneliti juga menguraikan keuntungan dan kerugian dari pendekatan metaheuristik yang berbeda dengan menunjukkan pentingnya hibridisasi metaheuristik serta integrasi metaheuristik dan metode pengoptimalan lainnya.

Beberapa masalah pada pengoptimalan praktis dan teoritis dari pencarian konfigurasi terbaik dari sekumpulan variabel untuk mencapai beberapa tujuan. Para peneliti bidang metaheuristik membagi menjadi dua kategori, pertama di mana solusi dikodekan dengan variabel bernilai riil, dan kedua solusi mana yang dikodekan dengan variabel diskrit. Pada kategori kedua ditemukan masalah yang disebut dengan masalah Combinatorial Optimization (CO). Menurut Papadimitriou dan Steiglitz [1982], dalam masalah CO, "Kami mencari objek dari titik terbatas atau mungkin tak terbatas", objek ini biasanya berupa bilangan bulat, subset, permutasi, atau struktur grafik.

Contoh untuk masalah CO adalah masalah Travelling Salesman problem (TSP), masalah Quadratic Assignment problem (QAP), Masalah Timetabling (Penjadwalan). Karena pentingnya masalah CO, banyak algoritma untuk mengatasi masalah tersebut yang telah dikembangkan. Algoritma ini dapat diklasifikasikan sebagai algoritma lengkap atau perkiraan. Algoritma lengkap dijamin untuk menemukan beberapa masalah CO dalam hitungan terbatas sebagai solusi optimal 
dan dalam waktu terbatas (Papadimitriou dan Steiglitz [1982] dan Nemhauser dan Wolsey [1988]). Namun, untuk masalah CO yang adalah NP -hard [Garey dan Johnson 1979], tidak ada algoritma waktu polinomial yang ada, dengan asumsi bahwa P6 = NP, oleh karena itu, metode yang lengkap mungkin memerlukan waktu komputasi eksponensial dalam kasus terburuk. Hal ini sering menyebabkan waktu yang terlalu tinggi untuk tujuan praktis. Dengan demikian, penggunaan metode perkiraan untuk memecahkan masalah CO telah mendapat perhatian lebih dan lebih dalam 30 tahun terakhir.

Di antara metode perkiraan dasar, biasanya kita membedakan antara metode konstruktif dan metode pencarian lokal, Algoritma konstruktif menghasilkan solusi dari nol dengan menambahkan - ke komponen solusi parsial yang awalnya kosong, sampai solusi selesai. Metode ini biasanya merupakan metode perkiraan tercepat, namun sering mengembalikan solusi dengan kualitas rendah bila dibandingkan dengan algoritma pencarian lokal.

Ada berbagai cara untuk mengklasifikasikan dan menggambarkan algoritma metaheuristik. Menanggapi karakteristik yang dipilih untuk membedakan di antara mereka, beberapa klasifikasi mungkin dilakukan, masing-masing menjadi hasil sudut pandang tertentu, secara singkat meringkas cara terpenting untuk mengklasifikasikan metaheuristik, mungkin cara yang paling intuitif untuk mengklasifikasikan metaheuristik didasarkan pada asal usul algoritma. Ada algoritma yang diilhami alam, seperti Algoritma Genetika dan Ant Algoritma, dan yang tidak terinspirasi dari alam seperti Tabu Search and Iterated Local Search.

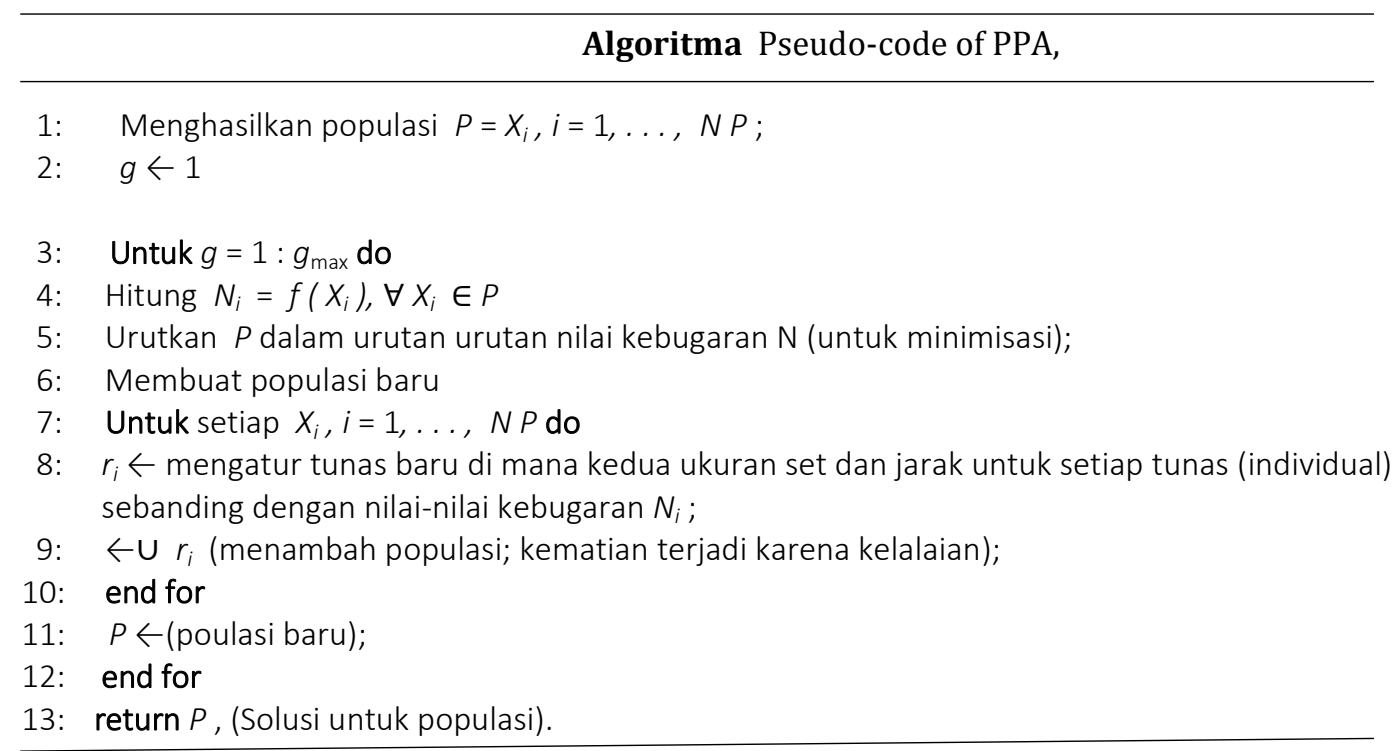

\subsection{Algoritma Hill Climbing}

Hill Climbing adalah pencarian heuristik yang digunakan untuk masalah optimisasi matematika dan keilmuan komputer di bidang Artificial Intelligence.Mengingat sejumlah besar input dan fungsi metaheuristik yang baik, algoritma ini berusaha menemukan solusi yang cukup baik untuk masalah 
tersebut. Solusi ini mungkin tidak optimal maksimum global, namun sudah dapat menemukan solusi yang diharapkan.

Dari definisi di atas, masalah optimisasi matematis menyiratkan bahwa hill climbing memecahkan masalah di mana kita perlu memaksimalkan atau meminimalkan fungsi nyata yang diberikan dengan memilih nilai dari input yang diberikan. Contoh-masalah salesman Traveling yang telah di paparkan diatas di mana kita perlu meminimalkan jarak yang ditempuh oleh salesman. Contoh dari kasus Algoritma Hill Climbing yang pernah ada ;

1. Ambil solusi kandidat dan uji kualitasnya.

2. Hasilkan solusi kandidat baru acak dan sedikit berbeda dan uji kualitasnya.

3. Jika kualitas solusi kandidat baru lebih baik daripada kualitas solusi kandidat sebelumnya, maka solusi kandidat baru ini menjadi solusi kandidat.

4. Ulangi langkah 2 dan 3 hingga waktu habis atau solusi ideal ditemukan.

Langkah kedua (menghasilkan solusi kandidat baru yang hanya sedikit berbeda dari solusi kandidat disebut "tweak" atau "berjalan"). Karena Hill Cilmbing hanya membutuhkan solusi kandidat baru yang sedikit berbeda dalam setiap percobaan, seringkali hanya mengarah ke solusi optimum lokal. Untuk meminimalkan kemungkinan mendapatkan hanya solusi optimal lokal, hill climbing diulang untuk beberapa jumlah waktu acak, ketika waktunya habis, solusi acak baru yang lebih jauh dari solusi terbaik sebelumnya akan dihasilkan, hill climbing lagi untuk beberapa jumlah waktu acak, dan seterusnya sampai solusi ideal ditemukan. Seluruh teknik ini dikenal sebagai random-restart hill-climbing.

Langkah menghasilkan solusi acak baru yang lebih jauh dari solusi terbaik sebelumnya disebut "menjelajah". Melakukan "eksplorasi" lebih dari satu kali diharapkan dapat memaksimalkan peluang mendapatkan solusi optimal global.

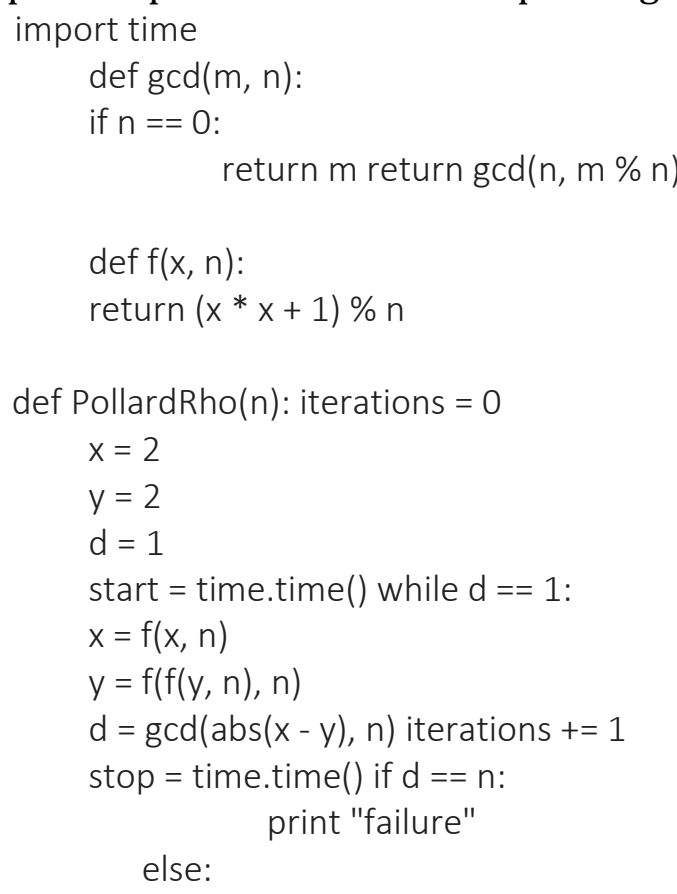




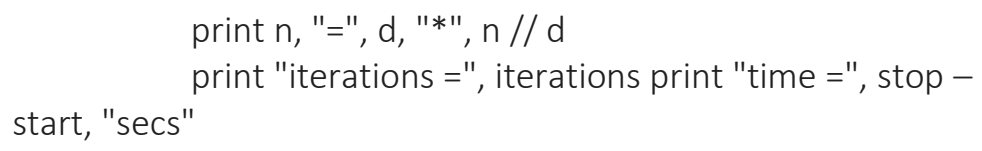

Saat menguji kualitas solusi kandidat baru ini, kita benar-benar mengalikan $p$ dan q, dan memeriksa apakah hasil dari perkalian ini cukup dekat dengan nilai $\mathrm{n}$. Jika cukup dekat, maka „berjalan" akan dilakukan selama 10 kali, tetapi jika tidak cukup dekat, maka dalam eksplorasi berikutnya, nilai acak baru p dan q yang jauh dari p dan q terbaik sebelumnya. nilai akan dihasilkan.

Karena modulus RSA adalah angka yang pasti, maka satu-satunya solusi ideal yang dapat diterima adalah ketika $\mathrm{pq}=\mathrm{n}$. Jika batas waktu tercapai dan pq masih tidak sama dengan $\mathrm{n}$, maka kita membiarkan algoritma berakhir tanpa hasil.
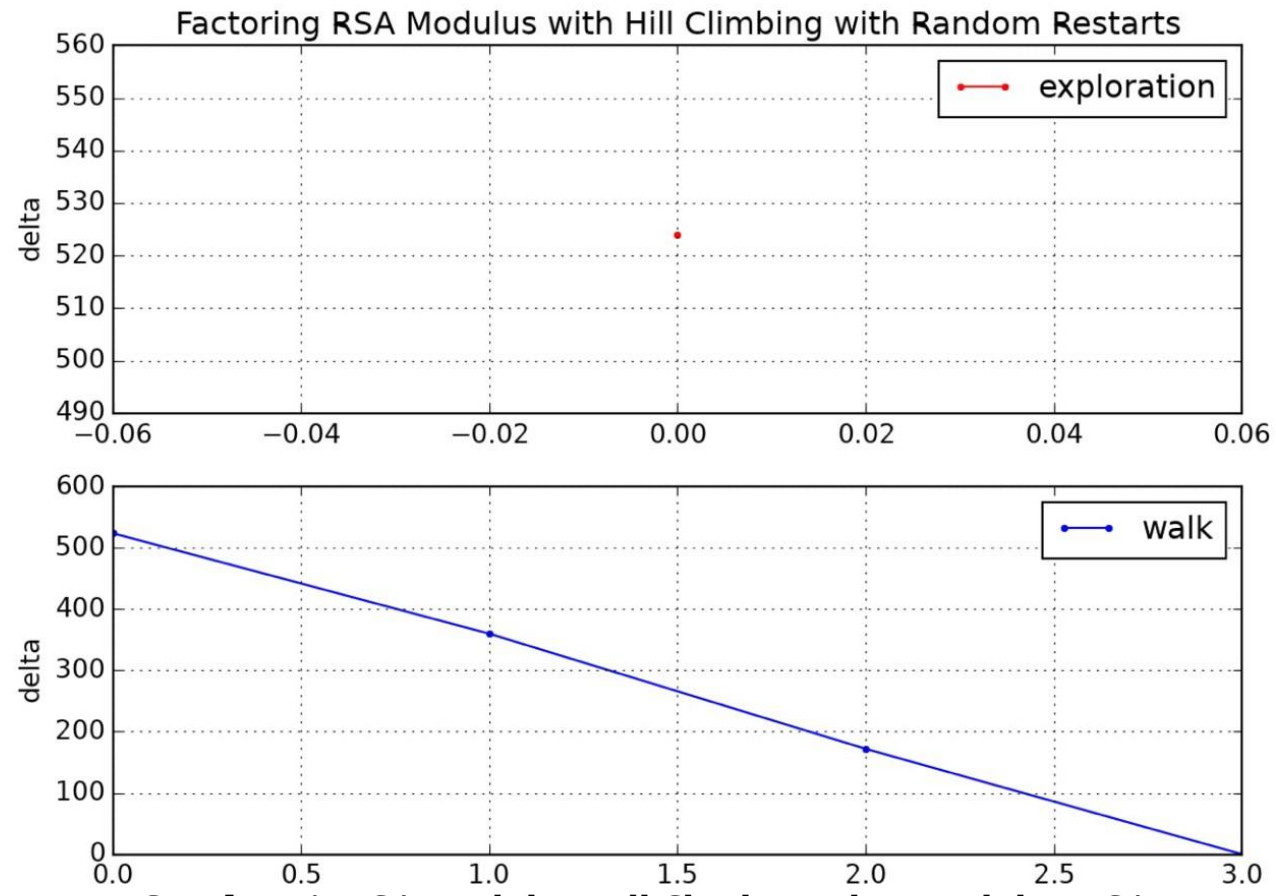

Gambar 1. RSA Modulus Hill Climbing dan Modulus RSA

Hal ini dapat dilihat dari Gambar 1, bahwa hanya satu titik merah (yang berarti satu eksplorasi) dan empat titik biru (yang berarti empat kali berjalan) diperlukan untuk faktor $\mathrm{n}=989=23 * 43$. Waktu yang dibutuhkan adalah 0,00448393821716 detik. 

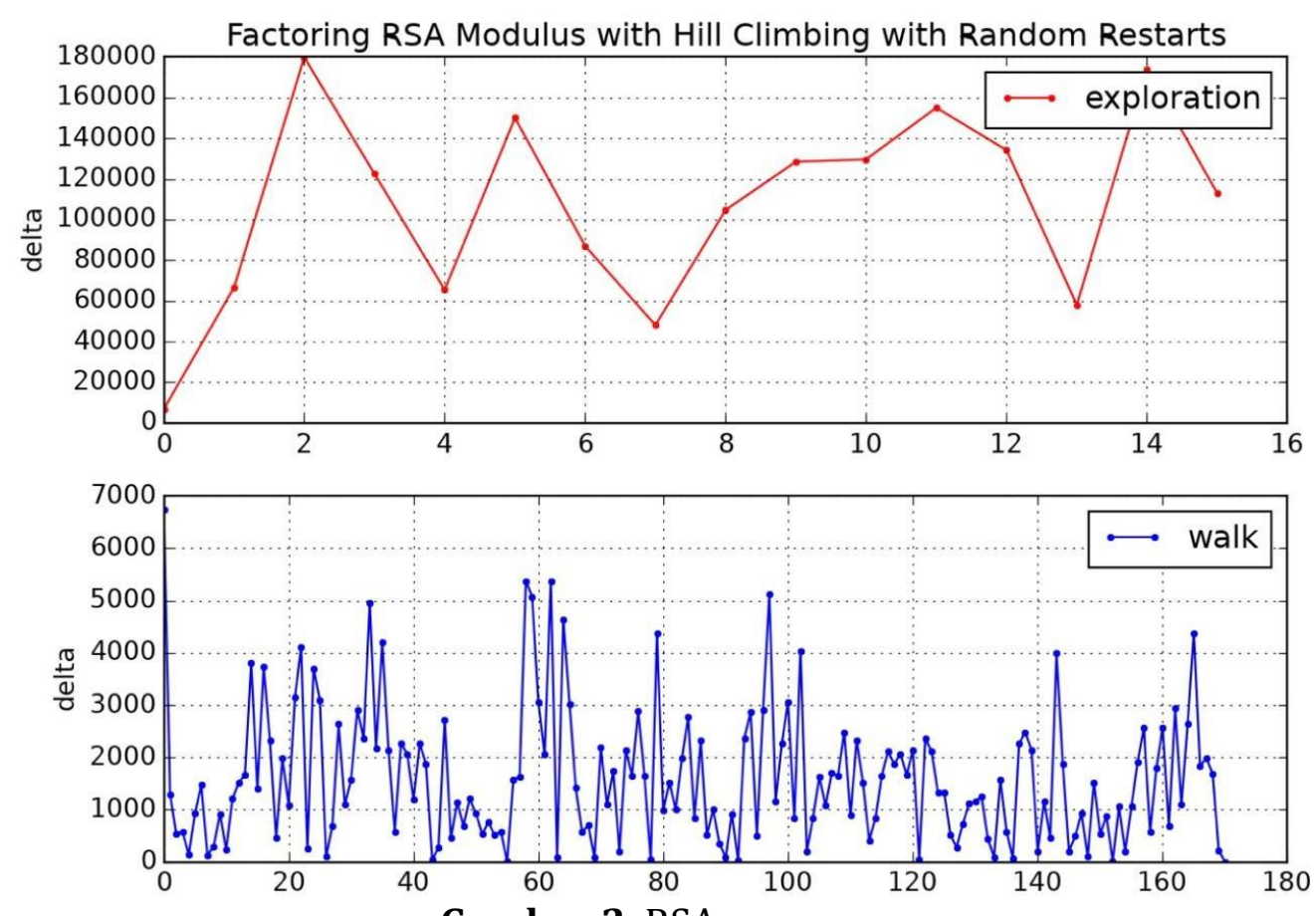

Gambar 2. RSA

Hal ini dapat dilihat dari Gambar 3, bahwa 6 eksplorasi dan lebih dari 300 berjalan diperlukan untuk faktor $\mathrm{n}=70531=251 * 281$. Waktu yang dibutuhkan adalah 0,0644018650055 detik. Perhatikan bahwa jumlah eksplorasi ke faktor $n$ = 70531 lebih rendah dari jumlah eksplorasi yang diperlukan untuk faktor $\mathrm{n}=$ 13289. Oleh karena itu, korelasi antara $\mathrm{n}$ dan jumlah eksplorasi mungkin tidak berbanding lurus.

\section{HASIL DAN PEMBAHASAN}

Pada pembahasan di atas, maka dapat di analisis dari perbandingan algoritma di atas, maka penulis membuat ide dari pendekatan pengembangan optimisasi dalam kombinatorial yaitu:

a. Tentukan titik Penyelesaian Layak.

b. Daerah ini diperkecil dengan menghilangkan (Eliminasi) daerah yang tidak memenuhi syarat layak cacah.

c. Identifikasi daerah yang dapat memberikan penyelesaian layak cacah Optimal

d. Dari titik yang diperoleh pada langkah 2, peroleh gradien arah ke daerah yang diperoleh di langkah 3

e. Tentukan seberapa jauh gerakan dari titik tadi sehingga kelayakan tetap terjamin.

f. Periksa titik yang diperoleh di langkah 5, apakah telah di daerah layak optimal.

g. Jika sudah lanjut ke langkah 8

h. Jika belum kembali ke langkah 4 
i. Lanjutkan gerakan dari titik yang diperoleh di langkah 5 dengan memperkecil daerah sehingga diperoleh titik yang berada di langkah 2 .

j. Stop.

Dari gambaran dari Ide dasar diatas penulis dapat menggambarkan metode penelitian melalui flow chart berikut :

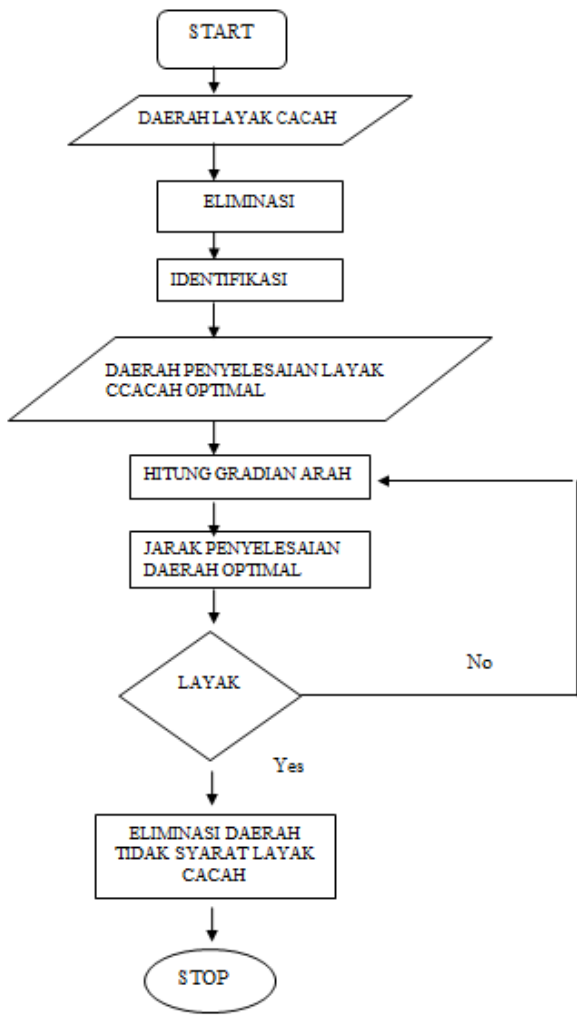

Gambar 3. Flowchart Pendekatan Pengembangan Metaheuristik

Defenisikan tentang daerah layak atau daerah penyelesaian dari suatu dari suatu persoalan optimisasi dengan kendala. Andaikan $\mathrm{g}(\mathrm{x})$ adalah fungsi kendala persoalan optimisasi dengan $\mathrm{g}=\mathrm{R}^{\mathrm{n}} \rightarrow \mathrm{R}$ maka himpunan $\{\mathrm{x}: \mathrm{g}(\mathrm{x})=\mathrm{b}\}$, b suatu konstanta disebut sebagai daerah layak atau daerah penyelesaian dari persoalan optimisasi tersebut. Untuk optimisasi kombinatorial, fungsi $\mathrm{g}(\mathrm{x})$ di defenisikan sebagai pemetaan $\mathrm{g}:\{0,1\}^{\mathrm{n}} \rightarrow\{0,1\}$, memperoleh daerah layak kebanyakan metode untuk menyelesaikan persoalan optimisasi kombinatorial mengajukan daerah layak, yaitu daerah yang di batasi kendala persoalan setelah dilakukan relaksasi seperti cacah atau biner terhadap variabel, misalnya metode Branch and Brend, Irisan bidang pada umumnya metode metaheuristik yang telah diajukan para peneliti lain, misalnya Genetika algoritma, simulated annealing, tabu search, plant propagation, metode metode ini tidak mempergunakan konsep daerah layak, tapi mengajukan titik awal penyelesaian .

Disebutkan diatas bahwa himpunan $\{\mathrm{x}: \mathrm{g}(\mathrm{x})=\mathrm{b}$ \}adalah daerah layak, andaikan himpunan 
$\mathrm{S}=\{\mathrm{x}: \mathrm{g}(\mathrm{x})=\mathrm{b}\}$

Maka jika terdapat $\mathrm{x} \in \mathrm{S}$ maka $\mathrm{x}$ disebut titik penyelesaian layak .

Penentuan titik penyelesaian layak

Andaikan bentuk umum dari persoalan Combinatial optimization dapat dituliskan sebagai berikut :

Maksimumkan $Z=f(x)$

Kendala $\quad g_{i}(x)=b_{i}, i=1,2, \ldots . . n$.

$$
x \in\{0,1\}
$$

Jika $f(x)$ dan $\mathrm{g}(\mathrm{x})(\mathrm{i}=\mathrm{b} . . . . . . \mathrm{m})$

Adalah linier maka persoalan (P) dapat dinyatakan dalam bentuk

Maksimumkan $Z=C^{\mathrm{T}} \mathrm{X}$

Kendala $\quad A \mathrm{x}=\mathrm{b}$

$$
\mathrm{x} \in\{0,1\}
$$

syarat biner di relaksasikan maka (PO) dapat ditulis sebagai

Maksimumkan $Z=C^{\mathrm{T}} \mathrm{X}$

Kendala $\quad A \times \mathrm{x}=\mathrm{b}$

$$
\mathrm{X} \geq 0
$$

Matriks kendala A berukuran minimum (m sejumlah baris, $\mathrm{n}$ jumlah kolom dapat dipartisi menjadi matriks besar (B) berukuran $\mathrm{m} \times \mathrm{m}$ dan matriks tersebut baris $(\mathrm{N})$ berukuran ( $\mathrm{m} \times$ (n.m)

Jadi dapat ditulis

$\mathrm{A}=(\mathrm{B} \mathrm{N})$

Analog vektor variabel $\mathrm{x}$ dapat dipartisi secara bersesuaian dengan vektor $\mathrm{X}_{\mathrm{B}}$ sebagai variabel basis dan $\mathrm{X}_{\mathrm{N}}$ variabel tak basis

Sekarang ekspresi $\mathrm{Ax}=\mathrm{b}$

Menjadi (B.N) $\left(\begin{array}{l}X_{B} \\ X_{N}\end{array}\right)=\mathrm{b}$

$\mathrm{B} \mathrm{X}_{\mathrm{B}}+\mathrm{NX}_{\mathrm{N}}=\mathrm{b}$

Atau $\mathrm{B} \mathrm{X}_{\mathrm{B}}=\mathrm{b}-\mathrm{NX}_{\mathrm{N}}$

Karena matriks $\mathrm{B}$ adalah matriks basis, maka matriks punya unsur $\left(\mathrm{B}^{-1}\right)$

Kalikan dari arah kiri persamaan dengan $\mathrm{B}^{-1}$ terdapat

$$
\begin{aligned}
& B^{-1} B x_{B}=B^{-1} b-B^{-1} N X_{N} \\
& I X_{B}-B^{-1} b-B^{-1} N X_{N}
\end{aligned}
$$

Jadi $\quad \mathrm{X}_{\mathrm{B}}=\mathrm{B}^{-1} \mathrm{~b}-\mathrm{B}^{-1} \mathrm{~N} \mathrm{X}_{\mathrm{N}}$

Nilai $X_{n}$ adalah 0 , dari $\mathrm{x} \leq 0$

Sehingga diperoleh titik penyelesaian layak untuk (PL) sebagai

$$
\mathbf{X}_{\mathrm{B}}=\boldsymbol{\beta}
$$

Dengan $\beta=B^{-1} b$ 


\section{KESIMPULAN}

Adapun kesimpulan dari hasil penelitian ini adalah sebagai berikut.

a. Model ini dapat menyelesaikan persoalan optimisasi secara efisien, dengan waktu yang cepat dan dengan penyelesaian terbaik (optimum).

b. Dengan pendekatan pengembangan metode metaheuristik penyelesaian optimisasi kombinatorial cepat terselesaikan, dengan menentukan daerah layak yang dibuktikan dengan pembuktian analitik dan eksak, sehingga di dapatkan variabel dari daerah layak tersebut.

c. Model pengembangan dengan menggunakan metode metaheuristik ini pada dasarnya adalah metode approximasi, metode pendekatan optimasi, akan tetapi dengan pengujian dan validasi matematis sehingga di dapatkan penyelesaian optimal.

d. Penelitian ini membuat sebuah model baru yang bisa di gunakan untuk permasalahan optimisasi lainnya, karena NP = Permasalahan optimisasi yang penyelesaiannya dapat diverifikasi/dibuktikan berada dalam batasan waktu polinomial ( $\mathbf{O}\left(\mathbf{n}^{\wedge} \mathbf{k}\right)$ dimana $n$ adalah ukuran permasalahannya dan $\mathrm{k}$ adalah konstanta.

\section{DAFTAR PUSTAKA}

[1] A.M. Geoffrion (1972). A Generalized Benders Decomposition, J. Op-tim. Theory Appl., 10 (4), 237-260

[2] Bienstock D, Computational study of a family of mixed-integer quadratic programming problems, Mathematical Programming, 74 (1996), pp. 121-140.

[3] Bonami P, Kilinc M, Linderoth J. 2009. Algorithms and software for convex mixed integer nonlinear programs. Technical report \#1664, Computer Science Department, Univ. of Wisconsin-Madison.

[4] C. D'Ambrosio, A. Frangioni, L. Liberti, A.Lodi. Experiments with a Feasibility Pump approachfor non-convex MINLPs. In: P. Festa(ed) Proceedings of the 9th Synposiumon Experimental Algorithms (SEA 2010), Lecture Notes in Computer Science, vol. 6049. Springer, Berlin (2010)

[5] C. D’Ambrosio, A. Frangioni, L. Liberti, A. Lodi. A storm of Feasibility Pump for non-convex MINLP. Tech. Rep. OR-10-13, DEIS, Universita di Bologna (2010)

[6] Danna E, Rothberg E, and C. LePape, Exploring relaxation induced neighborhoods to improve MIP solutions, Mathematical Programming, 102 (2005),pp. 71-90.

[7] Fernandes F P, Costa M F P, Rocha A M A C, Fernandes E M G P. 2016. Improving efficiency of a multistart with interrupted Hooke-and-Jeeves filter search for solving MINLP problems. Int. Conf. on Computational Sciences and its Applications, pp. 345-358.

[8] Flores-Tlacuahuac A and L. T. Biegler, Simultaneous mixed-integer dynamic optimization for integrated design and control, Computers and Chemical Engineering, 31 (2007), pp. 648-656.

[9] G. Nannicini and P. Belotti, Local Branching for MINPs. Technical Report workingpaper, CMU, 2009.

[10] G. Nannicini, P. Belotti. Rounding-based heuristics for non-convex MINLPs. In: P. Bonami, L. Liberti, A. Miller, A. Sartenear (eds). Proceedings of the European Workshop on MINLP. CIRM, Marseille, France (2009).

[11] Kaya 0, Urek B. (2016). A mixed integer nonlinear model and heuristic solutions for location, inventory and pricing decisions in a closed loop supply chain. Competers \& Operations Research, 65, 93-103.

[12] Kim J S, and Edgar T F. (2014) Optimal scheduling of combined heat and powerplants using mixed-integer nonlinear programming, Energy, 77, 675-690 
[13] M. A. Duran and I. E Grossmann, An Outer-Approximation Algorithm For a class of MixedInteger Nonlinear Programs, Mathematical Programming 36 (1986) 307.

[14] M. Fischetti, F. Glover, A. Lodi. The Feasibility Pump. Mathematical Programming A 104(1), 91-104 (2005). 